\title{
A NEW SPECIES OF DALBERGIA (LEGUMINOSAE, DALBERGIEAE) FROM WESTERN AFRICA
}

\author{
CAREL C.H. JONGKIND \\ Nationaal Herbarium Nederland, Wageningen University branch (Herbarium Vadense), \\ Generaal Foulkesweg 37, 6703 BL Wageningen, The Netherlands \\ e-mail: Carel.Jongkind@wur.nl
}

\begin{abstract}
SUMMARY
Dalbergia hepperi from Western Africa is described and illustrated. The combination of glabrous ovaries, flat and glabrous fruits and ovate to obovate leaflets with a conspicuous acuminate apex is not known from any other Dalbergia species from this region.
\end{abstract}

Key words: Leguminosae, Dalbergia, Africa, Liberia, Sierra Leone, taxonomy.

\section{INTRODUCTION}

When going through the literature and the herbarium collections from Western Africa for the ECOSYN project (see acknowledgements) we have identified several species new to science. One of them was a Dalbergia liana from the wet lowland forest, a species with already a long history. This species was first recognized by Dinklage, who did collect it in 1898 in Liberia, and did give it, together with Harms, the name Dalbergia liberiae. However, this name, written on the label of Dinklage 2030 in Zürich and mentioned in the overview of the work of Dinklage by Mildbraed (1937: 235), was never validated. Two other specimens of this species were seen by Hepper for his work for the Flora of West Tropical Africa. In 1954 he did write on the herbarium sheet of Dalziel 1016 in Kew "This matches nothing else in the herbarium .... It appears to be a new sp. but this one sheet is too poor to call a type." On the second sheet, N.W. Thomas 8361 in Kew, he wrote "Dalbergia oligophylla Bak. ex Hutch. \& Dalz. Although not previously recorded from Sierra Leone", however, in the Flora of West Tropical Africa he describes D. oligophylla as a mountain species not found west of Mount Cameroon (Hepper, 1958: 516). Strange enough both specimens are not cited by him in the Flora of West Tropical Africa. The specimen Dinklage 2030 was not seen by Hepper nor did he mention the name $D$. liberiae in his publication. More recently two new specimens of this species were collected in Liberia near Monrovia.

The combination of glabrous ovaries, glabrous and flat fruits and sparingly hairy to glabrous leaves with acuminate leaflets is not known in another Dalbergia species from this region. The two Dalbergia species from Western Africa that look most related to the new species are D. adamii Berhaut (1976: 170) and D. oligophylla. Dalbergia adamii (Fig. 1a-c; Map 1) differs by its hairy ovary, the more slender leaflets with a different venation and the smaller calyx-lobes. Dalbergia oligophylla is a mountainous 


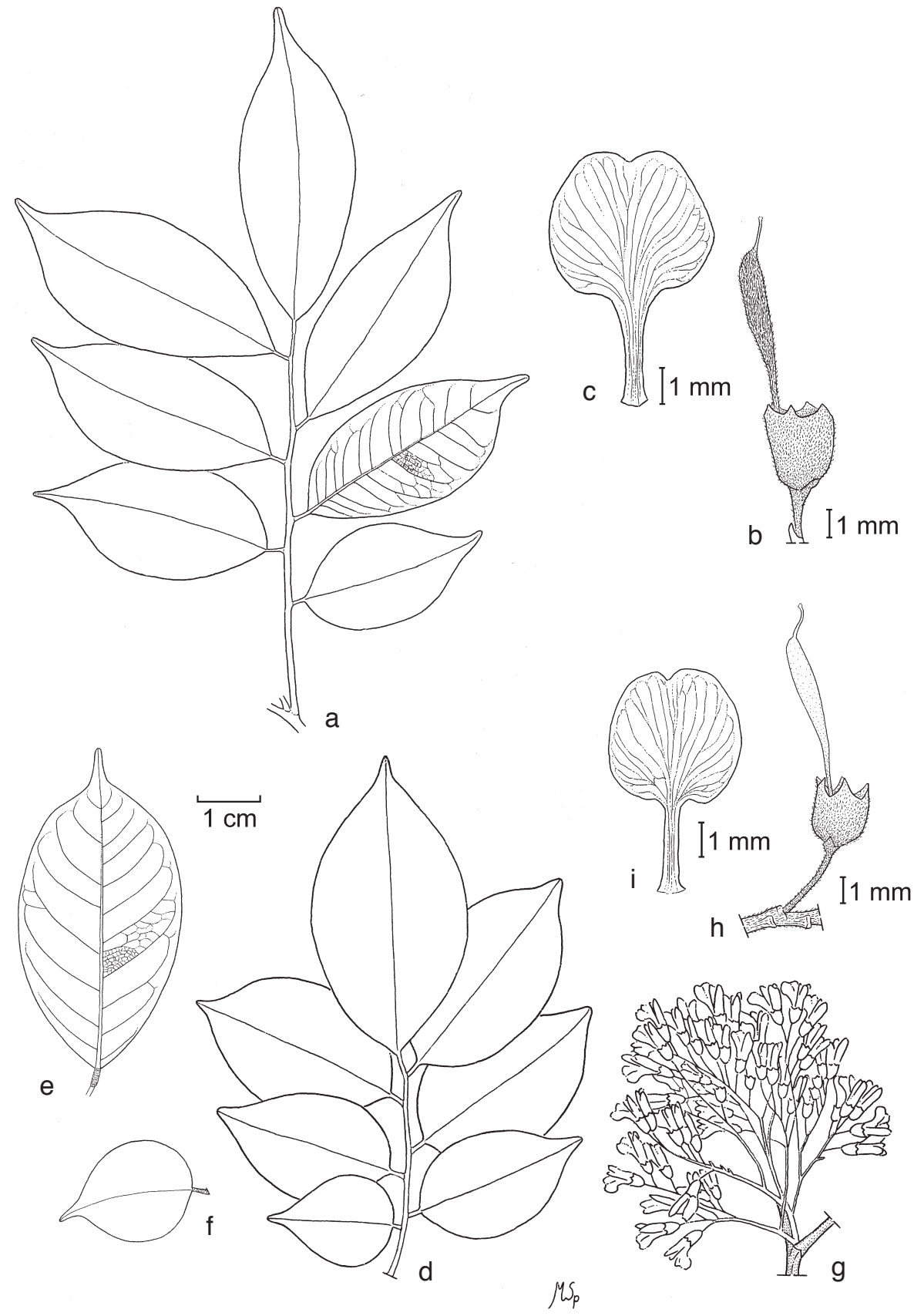

Fig. 1. a-c. Dalbergia adamii Berhaut. a. Leaf; b. calyx and ovary; c. standard. - d-i. Dalbergia hepperi Jongkind. d. Leaf; e. top-leaflet; f. basal-leaflet; g. inflorescence; h. calyx and ovary; i. standard (a-c: Bos 2613; d, h: Voorhoeve 423; e, f: N.W. Thomas 8361; g, j: P.P.C. van Meer 160). 
species with leaflets with a clearly hairy lower leaf-side and an acute apex, and different venation compared to the new species.

A key to all Dalbergia species from Western Africa, including D. hepperi, has recently been published in the Guide to the Woody Plants of Western African Forests (p. 810) by W. Hawthorne \& C. Jongkind.

Dalbergia hepperi Jongkind, spec. nov. - Fig. 1d-i; Map 1

Dalbergia adamii Berhaut affinis, sed carpellis glabris, lobi calycis majoribus, foliolorum discrepante nervatione, praecipae differt. - Typus: P.P.C. van Meer 160 (holo WAG; iso BR, MO), Liberia, c. 18 miles from Monrovia on the road to Kakata, 24 Aug. 1965.

Liana up to $30 \mathrm{~m}$ high. Young twigs densely appressed hairy. Leaves imparipinnate with 5-7 leaflets, up to $17 \mathrm{~cm}$ long. Petiole 11-28 mm long, pulvinus 4-6 mm. Rachis 28-70 mm long. Leaflets alternate, ovate or elliptic to obovate, or almost oblong, 25-90 by $12-46 \mathrm{~mm}$, both sides with scattered appressed hairs $<1 \mathrm{~mm}$ long or glabrous, base rounded, apex clearly but shortly acuminate, midrib impressed above, 5-7 pairs of inconspicuous main lateral nerves; basic lateral leaflets usually clearly asymmetrical. Petiolules 3-5 mm long. Inflorescence axillary, paniculate, densely branched, up to $5 \mathrm{~cm}$ long, branches densely appressed hairy, bracteoles c. $1 \mathrm{~mm}$ long. Flowers with strong sweet scent; pedicel c. $4 \mathrm{~mm}$ long. Calyx 3.5 by $2 \mathrm{~mm}$, densely appressed hairy, lobes deltoid, $0.7 \mathrm{~mm}$ long. Petals glabrous, white. Standard 6.5 by $4 \mathrm{~mm}$, blade emarginated and almost reflexed. Wings $6.5 \mathrm{~mm}$ long. Keel $6.5 \mathrm{~mm}$ long. Stamens 10 , united into two bundles of 5 each, $6.5 \mathrm{~mm}$ long, glabrous, anthers $0.3 \mathrm{~mm}$ long, yellow. Ovary $2 \mathrm{~mm}$ long, glabrous or with a few hairs along the margin, stipe $2.5 \mathrm{~mm}$

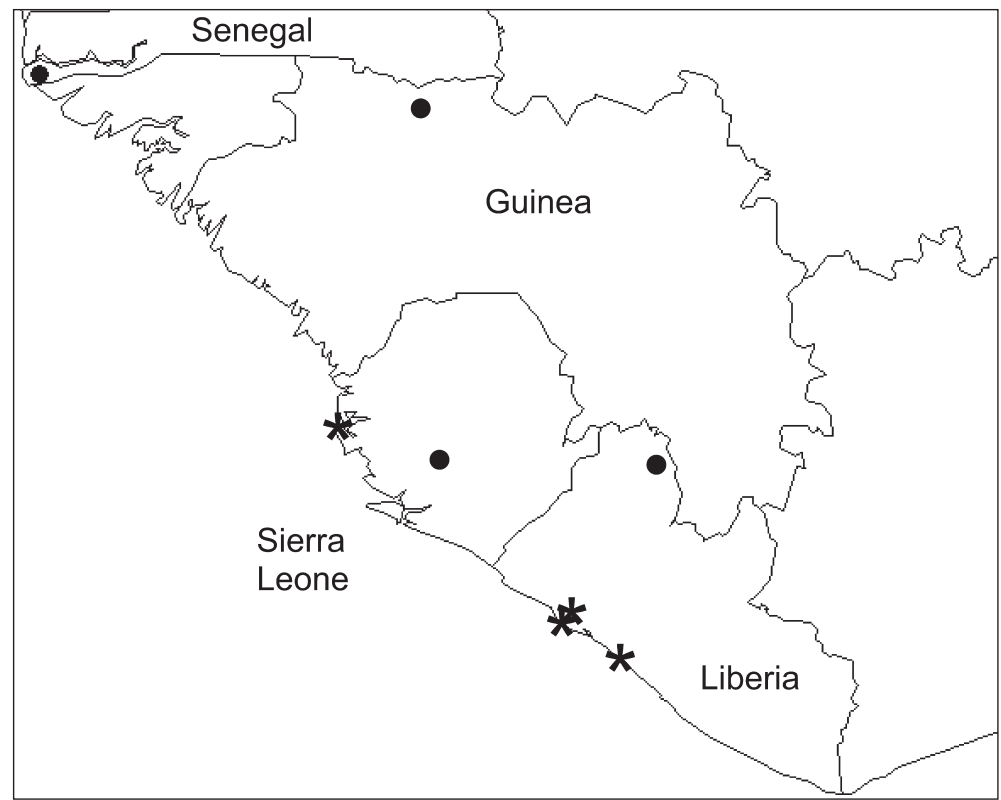

Map 1. Distribution of Dalbergia hepperi Jongkind $(*$ and Dalbergia adamii Berhaut 
long, style $1.7 \mathrm{~mm}$ long. Pod 1-seeded, strap-like, flat, indehiscent, glabrous, diffusely veined, c. 6 by $1.5 \mathrm{~cm}$, with more or less parallel sides, rather abruptly rounded at the ends, stipe $5 \mathrm{~mm}$ long.

Distribution - Sierra Leone and Liberia.

Habitat - Wet tropical lowland forest.

Additional material examined:

LIBERIA: Dinklage 2030 (Z), Grand Bassa, 4 Sept. 1898; Voorhoeve 423 (WAG), Devilsbush, Paynesville, Aug. 1961. - SIERRA LEONE: Dalziel 1016 (K), Freetown, 22 Feb. 1914; N.W. Thomas 3861 (K), s.l., anno 1915.

\section{ACKNOWLEDGEMENTS}

The work resulting in this publication was carried out in the context of the ECOSYN project, a research project on plant biodiversity and management of West African forests. This project is funded by the European Community (CEC-DG Development Action Plan).

I am grateful to Marjolein Spitteler for preparing the illustration.

\section{REFERENCES}

Berhaut, J. 1976. Flore illustrée du Sénégal, 5: 170, 171. Gouvernement du Sénégal, Ministère du Développement Rurale, Direction des Eaux et Forêts, Dakar.

Hawthorne, W.D. \& C.C.H. Jongkind. 2006. Woody plants of Western African forests. A guide to the forest trees, shrubs and lianes from Senegal to Ghana. Kew Publishing, London.

Hepper, F.N. 1958. In Flora of West Tropical Africa, second edition, part 1, 2: 513-516. Kew Publishing, London.

Mildbraed, J. (bearbeitet von) 1937. M. Dinklage ( $\dagger$ ). Verzeichnis der Flora von Liberia. Feddes Repert. Spec. Nov. Regni Veg. 41: 235-271. Berlin. 